\title{
ROLE OF TOURISM IN LOCAL DEVELOPMENT
}

\section{A CASE OF SARANGKOT HILL-TOP IN POKHARA, WESTERN NEPAL}

\author{
Narayan P. Bhusal \\ Reader \\ Department of Geography Education \\ Tribhuvan University, Kirtipur \\ bhusaln@hotmail.com
}

\begin{abstract}
Tourism management plan at the local level provides a framework for balanced development of a given area through the utilization of the existing tourism resources by the provision of tourism services that are required in order to attract the tourists from different parts of the world. Therefore, identifying and understanding of the natural, demographic and socio-cultural resource potential that enable an given area and its communities to shape tourism development according to local needs and within recognized environment and resource constrains. It is in this context the present paper is aimed to identify cultural and natural sites of tourism importance and problems and prospects of tourism for development in order to provide information on the basis of which can be undertaken sustainable actions for tourism development in Sarangkot VDC of Kaski distric, Western Nepal.
\end{abstract}

Key Words: Tourism, environment, resources, livelihood, cultural sites, historical monuments.

\section{Introduction}

Tourism has become one of the most important consequences of increasing human spatial mobility in modern times and civilization. In Theobald's view, tourism is "distinctly a twentieth-century phenomenon" because people in earlier periods tended to travel for purposes other than leisure (Theobald, 1994). Ostensibly, it has been motivated by the pursuit of pleasure and the belief that a temporary change of environment would provide or stimulate those pleasurable experiences (Griffin and Boele, 1997). Therefore, it has become one of the most spectacular phenomena of today's society and an agent for spreading and diversifying human impacts on the environment.

Since the early 1950s' international tourism has grown rapidly, particularly after the liberalization of foreign exchange and travel restrictions which characterized the years following World War II. The position in the present time is that tourism has achieved recognition as a major human economic activity not only on a global basis but also at regional and local levels (Jenkins, 1997). It is the fastest growing area in the world and there is no doubt that tourism has made a substantial contribution to the development process in most tourist receiving countries like Nepal. This is usually listed as the contribution to foreign exchange earnings, create economic activities and employment opportunities, generate national and regional economic development that economic development will generate both company and personal income and finally contribute to the government revenues through direct and indirection taxation (Jenkins, 1997).

After the real opening of Nepal in the summer of 1949 the numbers of foreign visitors to Nepal has been increasing steadily and tourism has deserves special emphasis both as one of the fastest growing industry in a world of increasing leisure and a new economic activity of great potential on the national economy (Gurung, 1989). Eco- tourism, mountaineering, trekking, sightseeing and cultural tourism are activities in Nepalese rural areas that have special significance. The beauty of Himalayas, mountains, hills and Terai with their ecosystems, habitats and rich cultural diversity, natural and cultural/historical sites/ monuments are the invaluable tourism resources that have been attracting an increasing number of national/domestic as well as international tourists from all over the world (Bhusal, 2004). Pokhara that lies in West-central Nepal is the District Head Quarters as well as Regional 
Centre of Western Development Region. Pokhara also is a most important centre of tourism attraction and entrance gate of the Annapurna region where more than 50 percent of the international tourists (who enter Nepal) visit and Sarangkot is one of the most important sites in Pokhara valley for panoramic views of the Annapurna range, Machhapuchhre, Phewa Lake and so on. This paper is aimed to deal with the role of tourism in local development and its problems and prospects in the study area.

\section{Study Area}

Sarangkot Village Development Committee (VDC) that lies to the northwest of Pokhara SubMetropolis in the central part of the Western Development Region of Nepal. It is one of the 43 VDCs in Kaski district that has a total of 1052 HHs and a population of 6737 with male population 3205 (47.2 percent) and female population 3584 (52.8 percent).

Sarangkot Village Development Committee is located in between 28.13' - 28.16' North Latitude and 83.55' 83.59' East Longitude and covers 1625 sq.km of area. It borders the Hemja VDC in the North and Pokhara Sub-Metropolitan City in the South. Again Pokhara Sub-Metropolitan City borders it at the East while Kaskikot/ Chapakot lies in the West. The altitude of this VDC ranges from $500 \mathrm{~m}$. - 1590m. above sea level (Map 1).

Map: 1 Sarangkot Village Development Committee in Kaski District

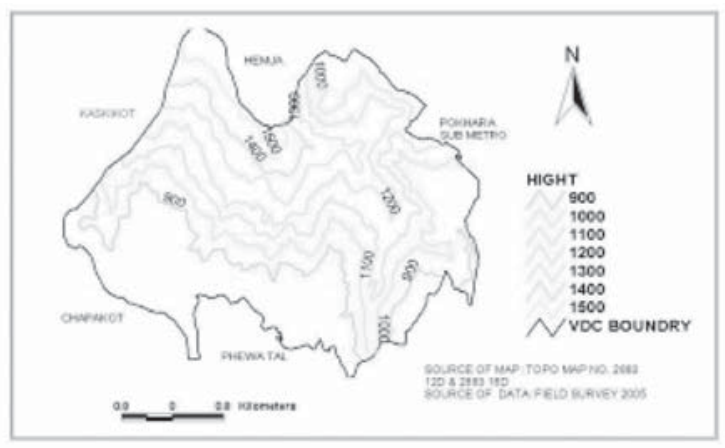

\section{Methods and Materials}

A village survey format was developed that include environmental aspect, demographic profile, economic profile, community and physical infrastructures and potential programs for the environmental management and socioeconomic enhancement of the local people in the VDC. Rapid/Participatory Rural Appraisal (R/PRA) was utilized in order to collect data and information quickly and efficiently. A number of group meetings were organized in different wards of the VDC in order to collect the information.

Relevant data and information were collected from Sarangkot VDC office, nearest meteorological stations, Kaski DDC office, Schools, health post, mothers groups, local clubs and NGOs, forest user groups and other offices located in the VDC. Various available maps and air photos of different time periods (especially land use of 1980 and present) were taken for field verification and update. After the completion of field verification and survey work necessary maps were prepared for Sarangkot VDC by applying Geographic Information System (GIS). Detailed observations of the VDC were conducted by applying the transect study method from Bindabasini temple (approx. 550m) in the east climbing to the Sarangkot hill (1590m) in the west and descends down to Fewa lake towards the south. During this period land use information were updated in the map and other relevant information were collected

\section{Biophysical Aspect}

Physiography is the expression of elevation as well as position of landforms and factors affecting the landforms, geology, climate, soil, etc. The upper part in the western side of the VDC lies in the high mountain physiographic region and lower part in the east and southern part falls under the middle mountain physiographic region. In the upper part (high mountain region) of the VDC bedrock is more metamorphosed than in the middle mountain and soils are widely variable whereas lower part of the VDC is a region of moderately metamorphosed sedimentary materials and soils are extremely variable reflecting differences in bed rock, geomorphology, micro-climate and past land use. Slopes of up to 30 are terraced using traditional methods. 
Climate is an important factor of the natural environment, which affects other factors such as flora, fauna, soil and human beings. In general the sub-tropical climate exists in the area below the altitude of $1500 \mathrm{~m}$.; temperate climate exists from $1500 \mathrm{~m} .-2000 \mathrm{~m}$. and temperate cold climate is found above $2000 \mathrm{~m}$ of altitude above the sea level. Climatological conditions mainly precipitation and air temperature are analyzed on the basis of meteorological records received from the nearest point, Lumle, located at an altitude of $1740 \mathrm{~m}$. above the sea level(Annex-1).

About 20 years ago, the forests area was negligible in this VDC but at present due to the efforts of the local community the area occupied by the forest is $7.08 \mathrm{Sq} . \mathrm{Km}$. (32.6 percent of the total area of VDC). Almost all the northern flank of the VDC is covered by dense forest that makes the green and natural surrounding attractive and amusing. Natural vegetation varies with altitude ranging from subtropical rain forest to temperate. The dominating vegetation species are Schima Wallichi and Wallichi, ShimaCastonopsis, Castamopsis Indica and bombax Ceiba, Acacia Catechu, Albizza and so on. Shorea Robusta is found to some extend in the lower parts and as the altitude increase the species of temperate vegetation are found in this VDC.

According to local residents, the number of wild life is increasing gradually in this VDC as per the growth of species and extension of forest density. At present this VDC has been the shelter of common leopard, jungle cat, crab eating mongoose and birds like Cattle egret, kingfishers, barbets, dark kite, black Patritge, sparrow, crow, jungle fowl, partridge, dove, pheasants and so on..

Harpan Khola, Yamdi Khola and Seti Khola are the major perennial water bodies that are drained the VDC. Fewa lake that lies in the southwest boarder of the VDC is the wonderful view from the Sarangkot hill and the major attraction for the tourists who visits in Pokhara.

\section{Socio-Cultural Aspects}

Sarangkot was named after the word of warfare: "Sarain". Every morning the armed warriors of
Kaski practiced from Kaskikot to Sarangkot as their regular routine of practices. Sarangkot has some special historical background and it was one of the many small principalities during the Baise - Chaubise period when Nepal was divided into many small kingdoms all over the country. Ancestor of Shah dynasty, King Kulmandan Shah, used to rule Kaski and his second palace along with a strong eastern fort for the defense against the enemies was in Sarangkot. The in charge of that fort was known as "Umarao" (Subedi, 2003).

There are some remnants of fort/palace in the Sarangkot area that are still visible. Such as there is a water reservoir (locally known as Raj Kuwa, King's well and that was the source of drinking water for the palace), a mortar, a pond, a small temple, a dozen of small pillars and tunnels are in disappearing conditions. According to local people most of the historical monuments and cultural artifacts are stolen. At the fort there was a small chamber of Bhume Dewata, a deity of land, where the local people offer Puja on the basis of Tantra during the festival of Bada Dashain and Chaite Dashain.

This VDC has a number of sites of cultural and religious importance. It has Buddhist stupas, monasteries and Hindu temples. At the top of the Sarangkot there is a Bhagawati temple of Gadess Durga Bhawani locally known as Bhumi Kalika where an attractive idol of goddess has been establishes within the temple. Likewise, in ward no. 2 of the VDC, there is a beautiful temple of Bagh Devi, locally believe as the goddess of forest and about 14 years ago local people constructed this temple to please the goddess of the forest in order to save the lives of local people and livestock from the attack of tiger. The surrounding of the temple is peaceful that has attracted the tourists to take a rest while climbing up the Sarangkot hill. There is a monastery named Nyahgayur Sangha Chhuding Monastery that was built 5 years ago from where one can have a spectacular views of Pokhara valley and have a look at the image of Lord Buddha installed within the monastery.

\section{Economic Aspect}

Occupational structure of Sarangkot VDC has been dominated by agriculture, where directly 
or indirectly almost all households are associated with agricultural activities. However, above 70 percent of the households do not have sufficient food supply and about 5 percent of the total households are land less. Therefore, these households are depending on farm laboring/wage earning, share-cropping and tourism related activities for their livelihood.

A household survey was under taken in ward no. 1,3,7,8 and 9 of the settlements (39 percent of the total HH with 2960 people) that are located along the hiking/trekking route from down Bindabasini temple up to Sarangkot hill area in order to find the occupational structures of the households and availability of tourism related services. According to the findings, occupational structures of Sarangkot VDC have been dominated by agriculture, providing employment for 5227 (86.2 percent) people that followed by business/hotel (9.4percent) and service (7. 9 percent). Service includes employment in governmental and nongovernmental organizations and private business including lodges and hotels.

\section{Physical Infrastructure}

Sarangkot can be more attractive site for tourists by developing physical infrastructures such as development of beautiful parks and picnic spots, forest resorts and botanical garden and so on. So far the development of physical infrastructures in the VDC is as follows:

- Most of the settlements in this VDC are linked with un-metalled road and total length of road is about $23 \mathrm{Km}$. and about 6 $\mathrm{Km}$. is already metalled under the Tourism Infrastructure Development Project.

Construction of a blacktopped motorable road of about $5 \mathrm{Km}$. starting from ward no. 2 of Pokhara Sub-Metropolitan City (Baglung Road, just west of Vindabasini temple) to ward no. 8 is just completed under the Tourism Infrastructure Development Project and graveled road passes through ward no. 3 and 5 to Sarangkot and reach to Kaskikot VDC in the west (Map 2).

Map: 2 Transportation (Major Roads and Foot Trails) Network in Sarangkot VDC

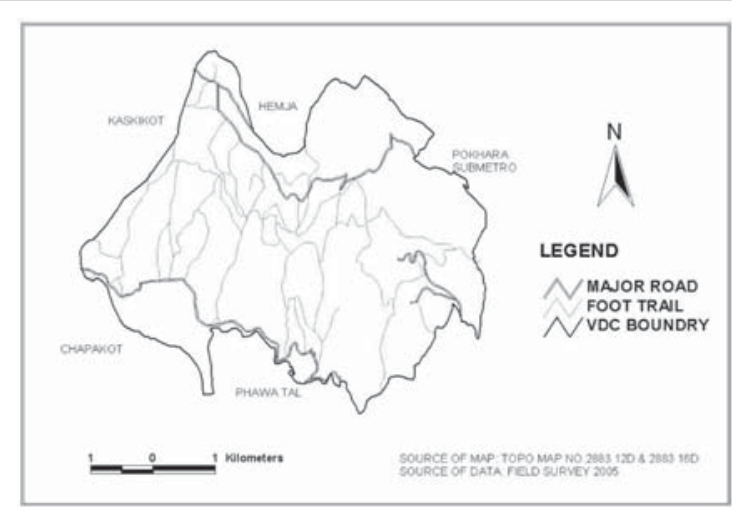

- A cemented step with iron railing from local track of Sarangkot top to the view tower (ward no.1 and 3) was constructed by DDC/ DFDP with the people's participation in the Fiscal Year-2059/60. VDC has planned to extend the railing path up to the road-head in order to attract the tourist towards the view tower. In order to provide the communication services to the local community one post office and one telephone line in the VDC are made available.

- More than 63 percent of the population in this VDC is dependent on agriculture for the lively hood. But due to the lack of adequate irrigation facilities agricultural production is not sufficient for the local consumption. Only 544.6 Ha. of land is under irrigation provision that is supporting in the production of vegetables in the winter season where the water is available

- Sarangkot hill area as the main tourism center has the provision of necessary tourism services and facilities that are required for the tourist. Other tourism trade centers along the road side (hiking route) from the Bindabasini temple (east of Sarangkot) are Lamagaun, Rohotepani, Gharelu, Binacular, Gothadi and Simsare. A number of lodges/restaurants, provisional shops, fruit shops, curio good shops and so on are distributed in order to provide the services for tourists and in return the people from these settlements are maintaining their livelihoods so far. 
- In this VDC about 90 percent of the population is benefited by the electrification. With the agreement between VDC and Pokhara Darshan Pvt Ltd. (Tourism Entrepreneur) there have been installed three telescopes at the top of the Sarangkot for tourists to have a panoramic view of the Himalayan range. Tourists are requested to pay Rs. 20 for 2 minutes in order to maintain the telescopes. But during our field survey 2 of them were not functioning properly.

\section{Social Infrastructure}

There are several governmental and nongovernmental organizations in this VDC and only some of them were found active for infrastructure development works. For example Jacees and Rotary Club have been supported in the construction of school buildings and day care centre for children and Lions Club supported in the construction of drinking water supply system. Likewise DFDP is contributing NRs.247166 for Biogass Plant and toilet construction in the VDC. DACAW, an INGO is working for Dalit and degraded class in the VDC. Sarangkot Sishu Bikas Kendra (a child care centre) that was registered in the DDC is managing to provide nutritive food, games, recreation and health facilities for the children of age between 2-5 years in the VDC with the financial support from American Himalayan Foundation and VDC.

Some of the local NGOs distributed in the VDC are Himali Balkalyan Samrakchhya Manch, Gunastariya Jeewan, Nepal, Sarangkot Samaj Sewa Yuba Club, Samarpit Yuva Club, Annapurna Janasakti Yuba Club, Ambika Mamata Yuba Club, Gandaki Yuba Cklub, Samarpit Yuba Club, Padekali Yuba Club and Sarangkot Langhali Yuba Club. These local clubs are active, to some extend, only in sport related activities and most of them are not active in generating awareness among the local people through appropriate environmental and social programs. Also there are seven Mother's Groups registered in the District Administrative Office, Kaski with objectives related to community/ women's development and environment management in Sarangkot VDC. Some of the governmental organizations like Nepal Blind
Organisation, Women and Small Farmer Development Programmes and Local Development Fund also exist in the VDC.

\section{Sarangkot Hill-Top as Eco-tourism Site}

Eco-tourism typically involves travel to destinations where flora, fauna and natural as well as cultural heritage are the primary attractions for the tourist. Since 1980 s environmentalists have considered eco-tourism as a critical endeavor, so that future generations may experience destinations relatively untouched by human intervention. The Brundtland Report has provided the most generally accepted definition that is "development that meets the needs of the present without compromising the ability of future generations to meet their own needs" (WCED, 1987). Espousing the Brundtland Report's principles but specifically geared to tourism, Globe 90' defined it as "meeting the needs of the present tourists and hosts while protecting and enhancing opportunity for the future" (Boele and Griffin,1997.

Therefore, eco-tourism is responsible travel to fragile, pristine and usually protected areas that strive to be low impact and often-small scale (as an alternate to mass tourism). Its purpose is to educate the traveler, provide funds for ecological conservation, directly benefit the economic development and political empowerment of local communities and foster respect for human rights (http:llen.wikipedia.org/wiki/). Responsible ecotourism includes programs that minimize the negative aspects of conventional tourism on the environment and enhance the cultural integrity of local people.

The Annapurna region of Western Nepal is well known as an integral part of eco-tourism to the tourist communities all over the world. It is surrounded by some of the highest mountains on earth and dissected by equally deep valleys world's deepest canyon, the Kaligandaki George at Dana of Mustang district. For millennia, many people from diverse ethnic backgrounds have carved a lifestyle out of its steep terraces and barren plateaus. In order to utilize this versatile and resourceful area for the welfare of both people and environment the Annapurna 
Conservation Area Project (ACAP) was established in 1986 under the aegis of the National Trust for Nature Conservation (NTNC).

The ACAP is the first and largest conservation area of Nepal with an area of 7629 square Km2 that covers the Mustang, Manang Lamjung, Mygdi and Kaski districts. This was initiated with the broad objective of conservation for development by adopting integrated and innovative approach of holistic vision in conservation and development that includes incorporating all the relevant issues of biophysical and socio-cultural conditions of the region (Gurung and Coursey, 1994). At present ACAP is the only successful systematic model that will be useful to replicate in other parts of the country for the conservation and development.

The ACAP have been taken a grass root approach where traditional rights and local institutions are respected and strengthened. The activities rely heavily on local participation and local management of natural resources including that of tourism impacts. Therefore, the guiding principles of the ACAP are sustainability and people's participation (Sharma, 2003). Sarangkot area that lies in the ACAP region is one of the most important eco- tourism sites. Spectacular natural environment of Pokhara valley - Its landscape, mountains, Seti and Kali rivers, Fewa and other lakes, flora and fauna as well as its cultural environment: ethnicity, social customs and so on are the major tourism attractions in Sarangkot area.

As a matter of fact there may be no other place in the world from which the great Himalayan peaks can be admired from such a close distance. Annapurna I $(8091 \mathrm{~m}$.) and its panoply of peaks lie only $50 \mathrm{Km}$ (31miles) away from Sarangkot hill-top. Machhapuchhare (6994m.) shoots straight up, without a single intervening ridge between it and Sarangkot hill $30 \mathrm{Km}$. (19 mile) distant. The horizon extends $140 \mathrm{Km}$. (87 miles) from Dhaulagiri (8167) to Himalchuli with an altitude of 7893m (Gurung, 1989). A pleasant day's walk will take tourist to the top of the Sarangkot hill over looking Fewa lake, beautiful Pokhara valley and incredible panoramic view of the whole Annapurna range.

An easier route for the Sarangkot hill top is to go to the Bindabasini temple in the north part of Pokhara Bazaar and take the road from there to Sarangkot. The trail back down to the lake is easy and the round trip should take four to five hours. Most of the tourists who visits to Pokhara do not wanted to miss this eco-tourism site, Sarangkot hill that is easier to reach and surrounded by beautiful views. The following table 1 shows the number of tourist visited by months in 2004 in Sarangkot VDC. As shown in

Table 1: Arrivals of Tourists at Sarangkot Hill Area by Months in 2004

\begin{tabular}{|l|c|c|}
\hline Month & $\begin{array}{c}\text { No. } \\
\text { tourists }\end{array}$ & $\begin{array}{c}\text { Percentage } \\
\text { of total }\end{array}$ \\
\hline January & 120 & 5.7 \\
\hline February & 150 & 7.1 \\
\hline March & 150 & 7.1 \\
\hline April & 100 & 4.8 \\
\hline May & 25 & 1.2 \\
\hline June & 75 & 3.6 \\
\hline July & 80 & 3.8 \\
\hline August & 200 & 9.5 \\
\hline September & 500 & 23.8 \\
\hline October & 600 & 28.6 \\
\hline November & 100 & 4.8 \\
\hline December & - & - \\
\hline Total & 2100 & 100 \\
\hline
\end{tabular}

Source: Sarangkot VDC, 2005. 
the table tourist peak months are September (23.8 percent) October (28.6 percent), January ( 5.7 percent) and February (7.1 percent). May (1.2 percent) and December are the slack months.

The number of tourist arrived in Pokhara prefer to go up to the Sarangkot. The data of two different years can be seen in Table 2 .

\section{Impact of Tourism on Sarangkot VDC}

\section{Positive Impact}

According to our survey findings the local people have considered the tourism as one of the most important source of earnings to support their livelihood. Most of the local people in this VDC have been involved in this sector directly / indirectly: some have involved as hotel/lodge and restaurant owners/workers, some as handicrafts and souvenir shopkeepers and some

Table 2: Arrivals of Tourist by Months in Pokhara and Sarangkot

\begin{tabular}{|c|c|c|c|c|}
\hline \multirow{2}{*}{ Month } & \multicolumn{4}{|c|}{ Number of tourist visited } \\
\cline { 2 - 5 } & \multicolumn{2}{|c|}{ Pokhara } & \multicolumn{2}{c|}{ Sarangkot } \\
\cline { 2 - 5 } & 1998 & 1999 & 2763 & 1999 \\
\hline January & 9089 & 9543 & 2631 & 3180 \\
\hline February & 9513 & 10054 & 3309 & 3573 \\
\hline March & 11758 & 12381 & 2922 & 3260 \\
\hline April & 11127 & 11683 & 1335 & 2482 \\
\hline May & 8205 & 7500 & 366 & 390 \\
\hline June & 3479 & 3571 & 264 & 280 \\
\hline July & 4183 & 3980 & 192 & 195 \\
\hline August & 6368 & 6700 & 1251 & 1319 \\
\hline September & 7973 & 8291 & 2637 & 3129 \\
\hline October & 11714 & 11563 & 3505 & 4395 \\
\hline November & 10993 & 10735 & 1941 & 2667 \\
\hline December & 9493 & 9545 & 25114 & 29154 \\
\hline Total & 103895 & 105546 & & \\
\hline
\end{tabular}

Tourism has grown enormously and its influence has spread widely since World War II. As it has grown, tourism has generated a broad range of significant impacts on the natural, social, cultural and economic environments of destinations. These have been extensively catalogued and their aspects to be consensus that while the net economic impact is usually beneficial, the other impacts of tourism are commonly detrimental (Mathieson and Wall, 1982).

The nature of the impact the both positive and negative depends upon the interaction, understanding, relationship, the duration and intensity of the contact between the hosts and guests. Therefore, the impact of tourism on the socio-cultural aspects of the host areas is very difficult to assess. Some of the impacts of tourism on the Sarangkot area that were identified during a short village survey period are presented in the following paragraphs. as tourist guides/portering. These are the tourism related economic activities in this VDC that are supporting in the upliftment of economic status of local community. Vehicle entrance tax, tourist donation, mortgaged land for paragliding are some of the source of income of the VDC.

Tourism development in Sarangkot VDC has played a significant role for the construction of RCC buildings, modern hotels and blacktopped road. This road was constructed with the assistance of Tourism Infrastructure Development Project.

Tourism has played a positive role in changing women's condition in the VDC where women are involved in managing hotel/restaurant, souvenir shop, kirana/cold drinks shop and in small cottage industries, Ama Samuha (Mothers Groups) and other local women groups are involving in the area of skill development for women who can produce a number of tourism 
related goods by mobilizing local resources. Local people felt that residence of Sarangkot area who are associated with tourism activities (including women) have notably learnt to respond their business in foreign language, especially in English.

Tourism development in this VDC has helped to increase contact outside the world. Some tourists have adopted few orphan and poor children and some Nepalese boys married with foreign girls have also managed a sort of joint venture in tourism related business.

Tourism has played a positive role in preservation of cultural practices and heritage sites in this VDC. Panche Baja (folk music, specially used during wedding ceremony) and local folk songs are some of the attraction for tourists and a group of tourists supported to a Pariyar family to purchase a set of Panche Baja and to train young people in the VDC.

Sanitation of the area has improved and no. of toilets has increase. A group of tourists from Belgium have supported to installed drum containers in order to collect litter of the area and awareness of the local people regarding the clean environment is in progress where they collect the wastage themselves

\section{Negative Impact}

The original significance of the tourism resources and indigenous cultural traditions of the local people are the basic phenomenon that has to be considered carefully by the both party, guests add host. Although much more benefits have been the results of the tourism business of the certain groups, mountain tourism is being problematic due to adverse impact that have been influenced on social, cultural and biological environment. The adverse effect of tourism includes the changes in the value system, individual behavior, loss or revised in traditional ceremonies (e.g. Rodi to pop song), traditional architecture, community organization, land use system, and so on. Modern RCC buildings replace traditional architectural design of house construction; traditionally inherited food (Gundruk, Dhindo etc.) items are replaced by imported food item. Similarly, the cultural dress is (eg., Gunyu,
Cholo, Ghalek etc. are superseded by modern imported dress.

Major negative impacts of tourism in the VDC are pollution, where bottles of mineral water, wrapper of biscuits/noodles, lunch box and plastics are some of the wastages produced by tourists. According to local people educational standard of the children has been affected by tourism seriously. Some of the children, instead of going to school generally swarm around the tourists either with an intention of begging or watching their activities. High school boys are used for tourist guides in long trekking routes during the school period that has seriously hampered the SLC results in the schools. As Sarangkot is close to Pokhara city and easily accessible by where thieves can go there and escape from the spot after stolen the goods, generally tourists have been the victims.

\section{Major Problems for the Development}

Poverty alleviation has always remained as a major challenge for overall development in Nepal and Sarangkot VDC also is under such circumstances where tourism can be a successful vehicle for overall development of the area. A prospect of eco-tourism in the Sarangkot VDC is high in terms of the available of tourism resources and easily accessibility. Therefore, eco-tourism can provide better opportunities for the local community of this VDC in order to uplift their socio-economic conditions. But, there exist a number of problems that are hampering to attract the tourists for longer time/ over night stay in the VDC.

\section{Inadequate Drinking Water Supply}

Adequacy of water, good accommodation and good communication are the basic facilities required for the development of the tourism. Inadequate of drinking water supply has been one of the most pressing problems for the tourist and local people in this VDC. Absence of shower, flushed toilets has made tourist feel uncomfortable. The hotels/lodges are far below the necessary standard in order to attract the more tourists who seek high standard of comfort and luxury. Due to the lack of adequate facilities most of the tourists visiting Sarangkot area just reach the top and immediately return back to 
hotels in Pokhara. Therefore, minimum infrastructural requirements for the tourism accommodations are to be fulfilled in order to attract the more night stay tourists.

\section{Environmental Problems}

Preservation and regular assessment of environment should be taken into consideration during the flow of tourists and the activities of the local people. Lack of promotional and conservation efforts, unhygienic trends and pollution are the main threats causing environmental problems, there is no provision for the public toilet facility and biscuits and noodles' rapper, bottles of mineral water and beers have created an unhealthy and irritated environment in the Sarangkot and along the road side area.

\section{Lack of Communication Facility}

There is no reliable communication facility in the Sarangkoit VDC. Some cordless sets are available in contact with the Phone-sets in Pokhara. Many tourists who visit Pokhara prefer hiking up to Sarangkot hill but the existing foot trail is not in good condition and not maintained regularly.

\section{Lack of Rest Place for Tourists}

Establishment and management of a beautiful park in the Sarangkot area for recreation, sight seeing, promotion and beautifications of environment is absolutely lacking. At present most of the tourists visiting to Sarangkot hill area do not stay for longer time, therefore in order to attract them for longer stay a park has to manage in the area and that will be an ornament for the eco-tourism site.

\section{Shortage of Food Grain for Local People}

As per the productivity of land is decreasing and population is increasing the food grain for the local people is not sufficient from the production of their land. Therefore provision of the food grain supply for the local people is necessary and creation of off-farm economic activities such as small and cottage industries will support to earn for their livelihood.

Recommendations for Tourism Development
In order to develop the Sarangkot area as model eco-tourism site of the national importance the following recommendations are proposed to take into consideration during the formulation of tourism management plan for Sarangkot VDC.

- During he construction of road/ trail and modern buildings in the VDC due consideration should be given on the environmental impact of such activities and conservation of natural resources.

- In this VDC drinking water supply must be adequate for the local people and tourist as well.

- Local houses also should be well facilitating with modern toilets and bathroom with adequate water supply.

- Most of the tourist entrepreneurs have to be trained and familiarized about the hotel/ lodge management and better hospitability. The services of local guides should have to be improved and systematized for impartment of necessary training.

- The souvenir shops, which seemed to be mostly selling imported goods that were made far away from the VDC. Therefore, preference should be given for the production of goods based on local raw materials.

- Development of cottage and small-scale industries in the VDC will certainly support the local people economically by producing the goods that are demanded by the tourists.

- Provision of telephone lines in all the wards of the VDC is recommended that will help the local people and tourists as well to communicate out side the VDC and nation.

- It is recommended to encourage the children of the Dalits to send the school that is lacking and children are wasting their times and deteriorating their way of life by using the drugs.

- It is essential to encourage the local people to construct the private toilets for their use and public toilets for the visitors. 
The implementation of the above mentioned recommendations would certainly support the Sarankot area in Pokhara valley to present as eco-tourism site of national and international importance.

\section{Conclusion}

It is essential to make the balance between socioeconomic development of the people and conservation and expansion of the tourism resources that are available in the VDC. Tourism is a most important industry can be the best vehicle for sustainable development if it balances nature and development as two sides of the single coin. This industry has a responsibility to the community in that it uses the community as a resource, sells it as a product and in the process affects the lives of its residents. It is suggested to put in mind that what is good for the local people will be good for the visitors. There fore preservation of cultural identity and traditions of local community and their socio-economic betterment and quality of life must have priority. Developing a tourism industry has both the positive and negative sides. But if the impacts are understood, minimizing the threats and weakness can maximize the strength and opportunities.

\section{Acknowledgement}

Field survey was conducted by a group of students of M. Ed. (Geography) Second year 2003-2005 batches under the direct field supervision of present author. Author sincerely acknowledges them.

\section{References}

Bhusal, Narayan P. (2002). Master Plan for Rapti Rriver Training and Environmental Awareness Program at Sauraha of Bachheuli Village Development Committee for Eco-Tourism Development in Royal Chitwan National Park, Central Nepal. Unpublished Report Submitted to Sauraha Hotel and Eco-Toirism Management Committee, CNP Buffer Zone Area. Chitwan

Griffin, Tony and Boele, Nicolette (1997). Alternative Paths to Sustainable Tourism: Problems, Prospects, Panaceas and Pipe-dreams. In: Go, M. Frank and Jenkins Carson L.(eds.), Tourism and Economic Development in Asia and Austrlasia. London: Cassell

Gurung, Chandra P. and M. De Coursey (1994). The Annapurna Conservation Project: A Pioneering Example of Sustainable Tourism. In: E. Carter and G. Lowman (eds.), Ecotourism: A Sustainable Options. London: John Wiley and Sons. Pp. 177-94.

Gurung, Harka (1989). Nepal Dimension Of Development. Kathmandu, Nepal

HMG/Nepal (2004). State of Nepal: Eco-Tourism. World Environment Day: 5 June 2004. Ministry of Population and Environment.

Jenkins, L. CarsonI (1997). Impacts of the development of International Tourism in the Asian region. I o, Frank M. and Jenkins, Carson L.(eds.), Tourism and Economic Development in Asia and Australasia. London: Casell.

Mathieson, A. and Wall, G.(1982).Tourism: Economic, Physical, and Social Impacts. London: Longman.

Sharma, Pitamber (2001). Mountain Environment and Tourism: The Nepal Experience. In: Proceedings of the International Symposium on the Himalayan Environments: Mountain Sciences and 
Ecotourism/Biodiversity. Hokkaido University Japan; Tribhuvan University, Nepal and The United Nations University, Japan.

Subedi, R.R. (2004). History of Kaski State. Kathmandu: Student Publications. Pp. 41-43.

The Himalayan Review (1998).Tourism Special Issue.Kathmandu: Nepal Geographical Society.

Theobald, W. F. (1994). The Context Meaning and Scope of Tourism. In Theobald, W.F. (ed.) Global Tourism: The Next Decade. Oxford: Butterworth-Heinemann.

World Commission on Environment and Development (WCED) (1987). Our Common Future. (Brundtland Commission Report). Oxford: Oxford University Press.

World Tourism Organization (WTO) (1996). Educating the Educators in Tourism: A Manuel of Tourism and Hospitality Education. Tourism Education and Training Centre. Spain: World Tourism Organization,

Annex-1: Precipitation in mm (1994 to 2004)

\begin{tabular}{|c|c|c|c|c|c|c|c|c|c|c|c|c|c|}
\hline Year & Jan & Feb & Mar & Apr & May & Jun & Jul & Aug & Sep & Oct & Nov & Dec & Total \\
\hline 1995 & 20 & 51 & 92 & 118 & 367 & 1402 & 1709 & 666 & 457 & 147 & 74 & 2 & 5102 \\
\hline 1996 & 51 & 79 & 91 & 20 & 280.8 & 603.3 & 950.2 & 860.9 & 589.0 & 112.8 & 0.0 & 0.0 & 3637.9 \\
\hline 1997 & 56.7 & 13.3 & 36.0 & 132.9 & 275.3 & 551.7 & 896.4 & 574.3 & 247.9 & 103.2 & 10.2 & 113.7 & 3011.6 \\
\hline 1998 & 0.0 & 26.2 & 91.6 & 191.4 & 450.2 & 689.7 & 932.3 & 1320.2 & 708.1 & 152.1 & 0.0 & 4.4 & 4565.8 \\
\hline 1999 & 7.4 & 18.6 & 0.0 & 12.5 & 783.9 & 788.2 & 1014.8 & 761.9 & 685.9 & 182.0 & 0.0 & 3.0 & 4258.2 \\
\hline 2000 & 17.2 & 12.6 & 40.2 & 175.2 & 596.4 & 831.4 & 1165.7 & 1120.1 & 551.3 & 82.9 & 8.8 & 0.0 & 4601.8 \\
\hline 2001 & 2.6 & 31.4 & 6.3 & 93.6 & 267.6 & 629.2 & 806.3 & 1376.5 & 691.3 & 118.5 & 25.0 & 0.0 & 4046.3 \\
\hline 2002 & 41.9 & 49.8 & 59.6 & 187.2 & 357.7 & 981.9 & 1649.6 & 359.3 & 308.8 & 127.2 & 2.0 & 0.0 & 392.5 \\
\hline 2003 & 32.8 & 77.0 & 65.9 & 146.0 & 217.8 & 732.7 & 1260.4 & 575.4 & 365.0 & 33.0 & 27.4 & 33.5 & 4166.9 \\
\hline 2004 & 36.6 & 7.0 & 44.3 & 245.5 & 261.2 & 558.0 & 1101.9 & 761.6 & 811.6 & 231.1 & 26.0 & 0.9 & 4086.7 \\
\hline Total & 265.3 & 366.4 & 526.8 & 1312.3 & 3855.4 & 7767.7 & 26333.3 & 8576.2 & 6015.7 & 2040.7 & 173.2 & $157 . .3$ & 414302.6 \\
\hline Ave & 26.53 & 36.64 & 52.68 & 132.23 & 385.54 & 776.77 & 2633.33 & 857.62 & 601.57 & 204.07 & 17.32 & 15.73 & 41430.26 \\
\hline
\end{tabular}

